\title{
Comment on "HAX1 Augments Cell Proliferation, Migration, Adhesion, and Invasion Induced by Urokinase-Type Plasminogen Activator Receptor"
}

\author{
Alicja Trebinska, Ryszard Konopinski, and Ewa A. Grzybowska \\ Cancer Center Institute, Roentgena 5, 02-781 Warsaw, Poland \\ Correspondence should be addressed to Ewa A. Grzybowska; ewag@coi.waw.pl
}

Received 26 February 2013; Accepted 9 May 2013

Academic Editor: James L. Mulshine

Copyright ( 2013 Alicja Trebinska et al. This is an open access article distributed under the Creative Commons Attribution License, which permits unrestricted use, distribution, and reproduction in any medium, provided the original work is properly cited.

Multifunctional HAX-1 protein is involved in the regulation of several key processes like calcium homeostasis, apoptosis, and cell migration. Clarification of its role in these or other processes and its molecular mechanisms of function remains to be established. Mekkawy et al. [1] report HAX-1 influence on cell proliferation, migration, adhesion, and invasion induced by the urokinase-type plasminogen activator receptor (uPAR), as a followup of the previous study, in which the authors demonstrated uPAR-HAX-1 interaction [2]. We would like to report our serious concerns about the HAX-1 expression system used in the study of Mekkawy et al., 2012 [1]. The authors use either pGEM-3Zf(+)HAX1 or pGEM$3 \mathrm{Zf}(+)$ as an empty vector to transfect human cell lines. These vectors are intended for in vitro transcription and propagation in bacteria; they are not mammalian expression vectors and do not possess the appropriate promoter sequences. pGEM-HAX-1 used in this study was obtained from Maria Olsson and is described in the work of Dufva et al. [3] as a vector generated for in vitro transcription by cloning HAX1 coding region into pGEM-3Zf $(+)$. Unless the vector was modified, we do not see the possibility of HAX-1 expression, other than endogenous, in the studied cell lines. Furthermore, no evidence of HAX-1 overexpression was provided (e.g., Western blot). Regarding these concerns, we consider the results indicating HAX-1 influence meaningless.

\section{References}

[1] A. H. Mekkawy, D. L. Morris, and M. H. Pourgholami, "HAX1 augments cell proliferation, migration, adhesion, and invasion induced by urokinase-type plasminogen activator receptor," Journal of Oncology, vol. 2012, Article ID 950749, 9 pages, 2012.

[2] A. H. Mekkawy, C. E. de Bock, Z. Lin, D. L. Morris, Y. Wang, and M. H. Pourgholami, "Novel protein interactors of urokinasetype plasminogen activator receptor," Biochemical and Biophysical Research Communications, vol. 399, no. 4, pp. 738-743, 2010.

[3] M. Dufva, M. Olsson, and L. Rymo, "Epstein-Barr virus nuclear antigen 5 interacts with HAX-1, a possible component of the B-cell receptor signalling pathway," Journal of General Virology, vol. 82, no. 7, pp. 1581-1587, 2001. 


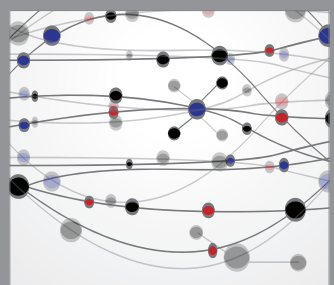

The Scientific World Journal
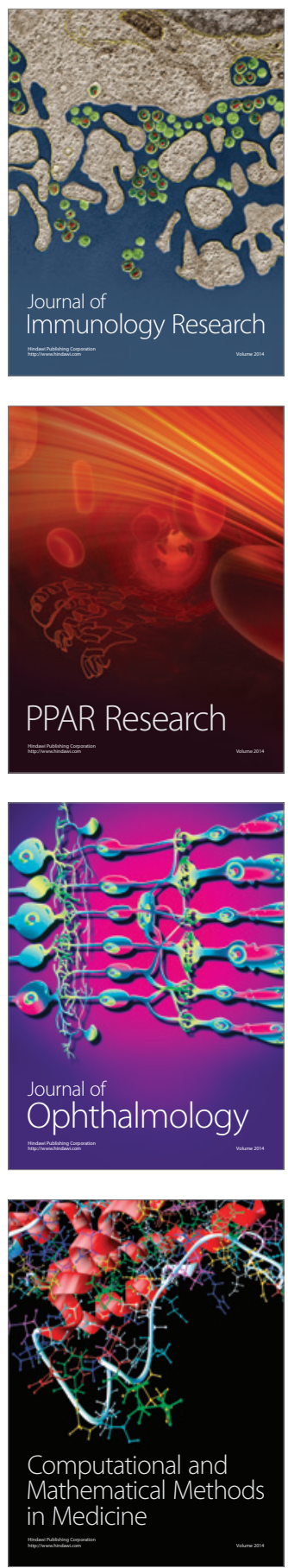

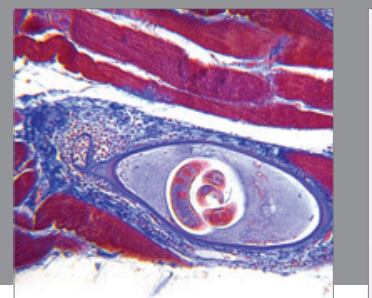

Gastroenterology

Research and Practice
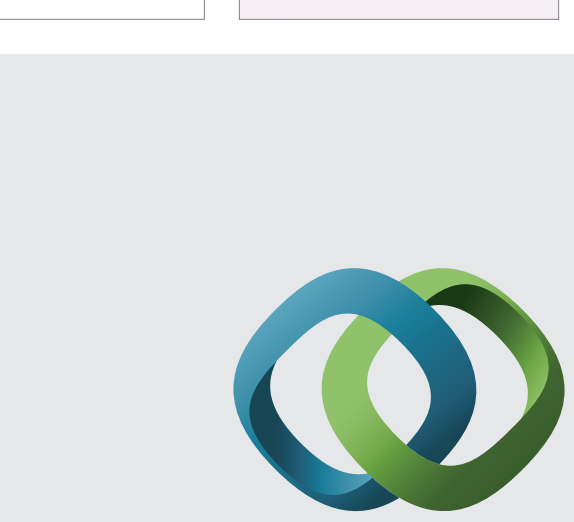

\section{Hindawi}

Submit your manuscripts at

http://www.hindawi.com
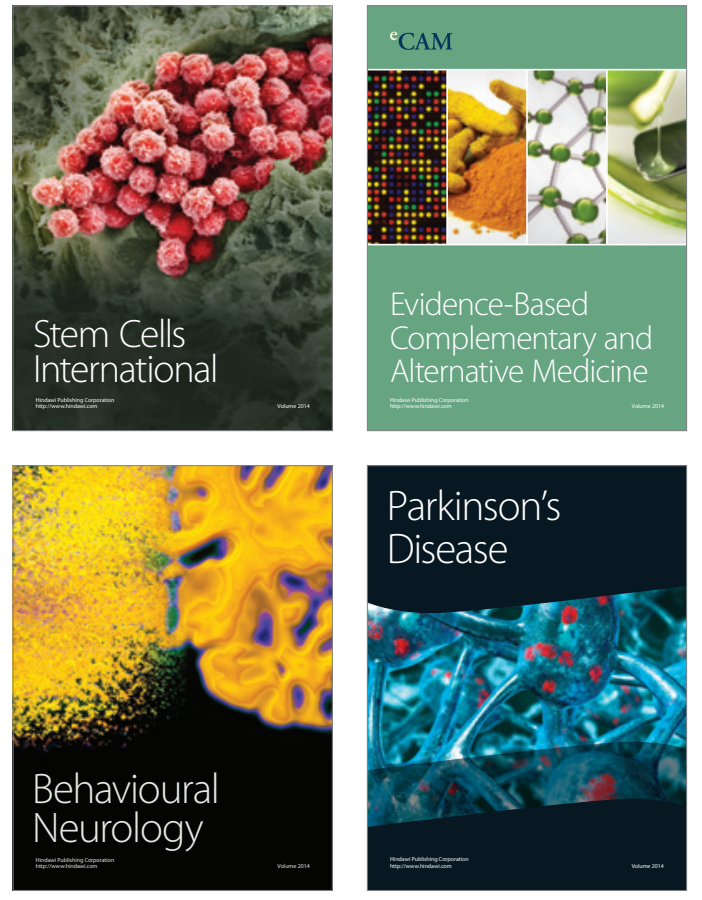
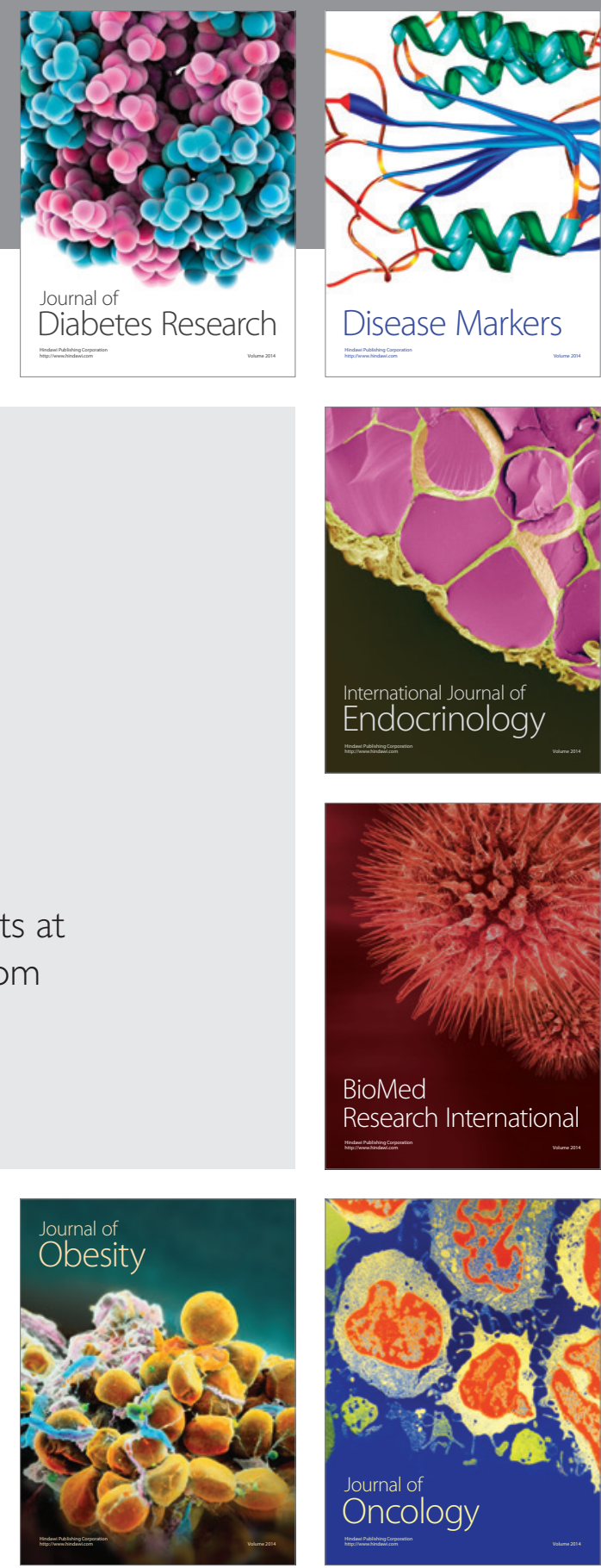

Disease Markers
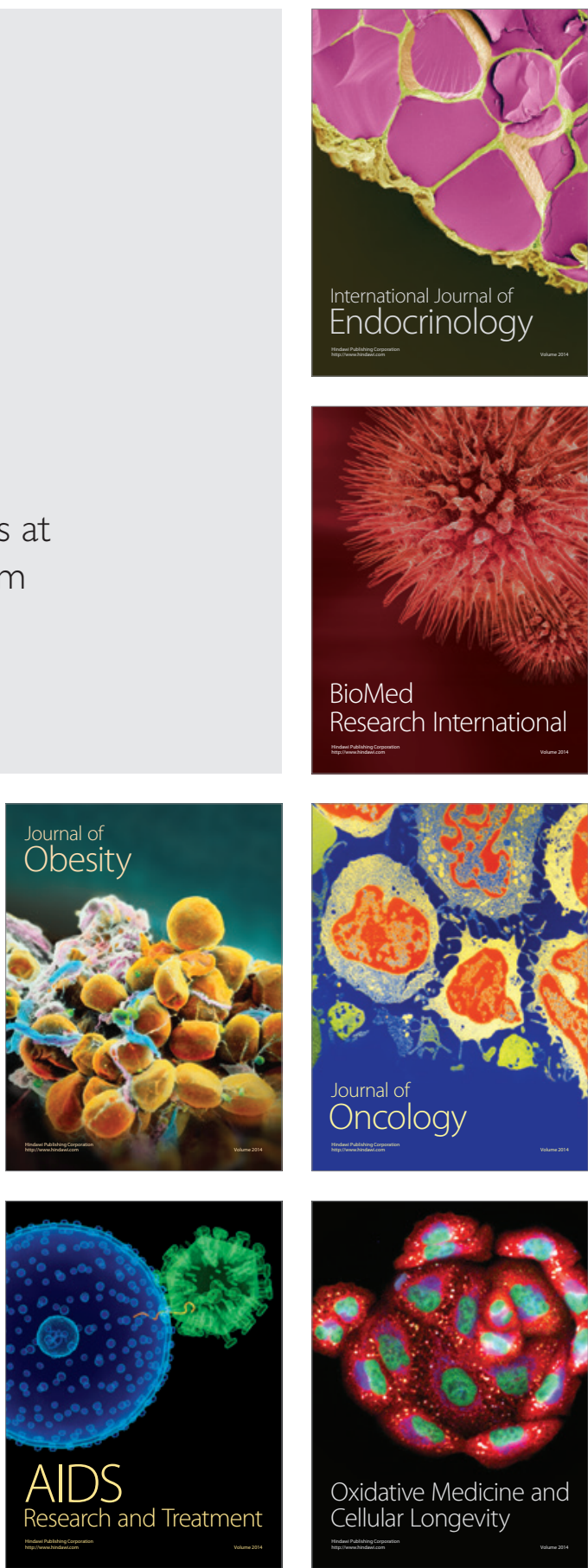